TITLE:

\title{
Chondroprotective effect of Alendronate in a rabbit model of osteoarthritis(Abstract_要旨 )
}

\section{$\operatorname{AUTHOR}(S)$ :}

Shirai, Takaaki

\section{CITATION:}

Shirai, Takaaki. Chondroprotective effect of Alendronate in a rabbit model of osteoarthritis. 京都大学, 2011, 博士(医学)

ISSUE DATE:

2011-03-23

URL:

http://hdl.handle.net/2433/142101

RIGHT: 


\begin{tabular}{|l|l|c|c|}
\hline 京都大学 & 博士 (医学) & 氏 名 & \multicolumn{1}{|c|}{ 白 井 孝 昭 } \\
\hline & Chondroprotective effect of Alendronate in a rabbit model of \\
論文題目 & $\begin{array}{l}\text { osteoarthritis } \\
\text { (アレンドロネー }\end{array}$
\end{tabular}

（アレンドロネートは家鬼変形性膝関節症モデルにおいて軟骨保護作用を有 す)

(論文内容の要旨)

変形性膝関節症 $(\mathrm{OA})$ は様々な要因から起こる進行性の疾患であり、高齢者の多数 が罹患し今後さらに増加すると見込まれる。OAの危険因子として、加齢、女性、肥満、 などが知られており、治療としては初期では運動療法、薬物療法が多く、未期になると手 術療法も選択される。一方骨粗鬆症も高齢者の活動性の低下や、寝たきりの主要因であり、 骨粗鬆症による骨折を予防することが、高齢者の ADL を低下させないために重要とされて いる。骨粗鬆症の治療として、食事療法、運動療法、薬物療法が一般的に行われているが、 近年アレンドロネート（AＬ）などのビスフォスフォネート製剤が骨粗鬆症による骨折 のリスクを直接的に減少させた、として注目されている。ともに中高年層が罹患するOA と骨粗鬆症であるが、最近OAに対するA L N の効果について臨床使用した報告が散見さ

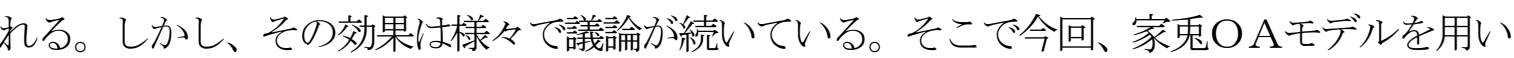
てA L Nの関節軟骨や軟骨下骨に対寸る作用を検証し、A L NのOA治療薬としての可能 性を追求した。

30 羽の日本白色家兔に対し、左膝は前十字勒帯を切離して実験的OAを作成し、右膝は sham 手術を施行した。15 羽に対して手術直後より A L N ( $0.14 \mathrm{mg} / \mathrm{kg})$ を週 1 回皮下注し、 残りの 15 羽に対しては生理食塩水(生食)を同様に皮下注し、実験終了まで続けた。それ ぞれ 5 羽ずつ、術後 2 週、4 週、1 2 週で屠殺した。まずA L N の効果を確かめるため、軟 骨下骨の骨量と厚さをマイクロ C Tを用いて評価し、組織切片において TRAP 染色で破骨 細胞の抑制の有無を評価した。続いて、膝関節軟骨は HE 染色、Safranin-0 染色にて組織 学的観察でスコアリングを行った。また膝関節周囲の骨棘についても評価した。さらに、 軟骨層においてマトリックスメタロプロテアーゼ 13 (MMP13) やX 型コラーゲン (COLX)、 インターロイキン $1-\beta$ （IL1- $\beta$ ）、血管内皮細胞増殖因子 (VEGF)、Receptor Activator of Nuclear Factor Kappa B Ligand（RANKL) などのOA変化に関連する蛋白の発現検索を免 疫染色にて行った。

術後 12 週で、軟骨下骨の骨量は、OA膝で咸少していたが、A L N投与により増加し ていた。軟骨下骨の厚さについては差がなかった。TRAP染色において、A L N投与に より破骨細胞数が減少していた。A L Nの骨に対する効果が確かめたのち膝軟骨の評価を 行うと、術後 12 週でOA膝では明らかな軟骨損傷が認められたが、A L N投与により O Aの進行は緩やかに抑制されていた。また関節周囲の骨棘についてもA L N投与で減少傾 向にあった。免疫染色では、軟骨層において MMP13 やCOLX、IL1- $\beta$ 、VEGF、RANKL の発現 がA L N投与により抑制されており、そのなかでRANKLについては石灰化軟骨層において もA L N投与により発現抑制されていた。

A L N投与により実験的OAにおける軟骨保護作用が認められた。A L Nが軟骨細胞に直 接㗢きかける作用はほとんどないと報告されている。ゆえに、A L NのOAに対する抑制 の機序として、軟骨下骨の骨量増加により軟骨に対する機械的ストレスが軽減されたこと があげられ、さらにOA進行に関与する chemical mediator の発現が抑制され軟骨変性の 進行が緩やかになったことも考えられる。本研究から、OAの初期においてALN投与
によりOA進行が抑制できる可能性があることが示唆された。

\section{（論文審查の結果の要旨）}

変形性膝関節症（以下 OA）における軟骨下骨の役割についてその重要性が認識され つつあ。骨粗鬆症の治療薬として知られるアレンドロネート（以下ALN）のOA に刘 する効果は議論が続いており、その作用機序については充分には解明されていない。家 兔を用いて実験的 OA モデルを作成し、ALN の OA に対する効果とその作用機序を解明 する研究を行った。その結果、ALN 投与は OA 進行に伴う軟骨下骨の骨量減少を抑制し、 さらに軟骨下骨における破骨細胞活性を抑制した。そして、膝関節の肉眼的、組織学的 観察において ALN 投与による軟骨保護作用が認められ、OA の進行が抑制されていた。 また、免疫学的検索にて OA 関連因子であるマトリックスメタロプロテアーゼ 13、イン ターロイキン 1 - $\beta$ 、X 型コラーゲン、血管内皮細胞増殖因子、receptor activator of nuclear factor $\kappa$ B ligand の軟骨層における発現が ALN 投与により抑制されていることを確認し た。これらの結果は、ALN が軟骨下骨の骨量を維持して軟骨に対する機械的ストレスを 減少させる作用とともに、軟骨層における OA 進行に寄与する因子の発現を抑制する作 用を合わせて軟骨を保護したことを示している。

以上の研究はOAにおけるALNの軟骨保護作用のメカニズムの解明に寄与寸るところ が多い。

したがって、本論文は博士 (医学) の学位論文として価值あるものと認める。

なお、本学位授与申請者は、平成 23 年 3 月 8 日実施の論文内容とそれに関連した試 問を受け、合格と認められたものである。

旨公開可能日： 